Document downloaded from:

http://hdl.handle.net/10251/84340

This paper must be cited as:

Nazer, A.; Paya Bernabeu, JJ.; Borrachero Rosado, MV.; Monzó Balbuena, JM. (2016). Use of ancient copper slags in portalnd cement and alkali activated cement matrices. Journal of Environmental Management. 167:115-123. doi:10.1016/j.jenvman.2015.11.024.

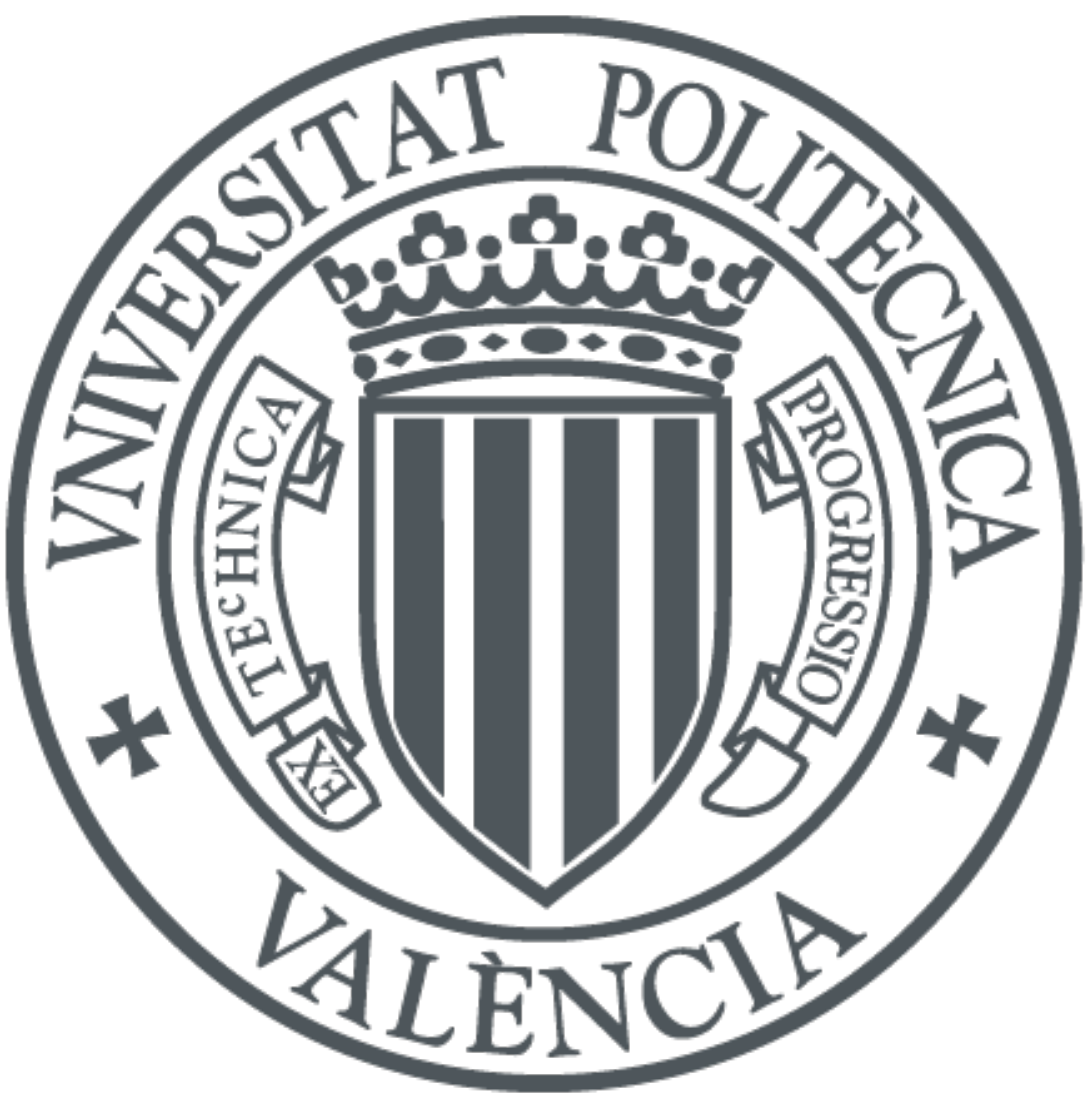

The final publication is available at

http://dx.doi.org/10.1016/j.jenvman.2015.11.024

Copyright Elsevier

Additional Information 


\title{
Use of ancient copper slags in Portland cement and alkali activated cement matrices
}

\author{
Amin Nazer ${ }^{\mathrm{a}, \mathrm{b}}$, Jordi Payáa, Victoria Borrachero ${ }^{\mathrm{a}}$, José Monzóa $\left.{ }^{*}\right)$ \\ ${ }^{a}$ Instituto de Ciencia y Tecnología del Hormigón ICITECH, Universitat Politècnica de València, Spain \\ Camino de Vera s/n, Edificio 4G, Valencia 46022, Spain; \\ ${ }^{b}$ Instituto Tecnológico, Universidad de Atacama, Copiapó, Chile \\ E-mails:amin.nazer@uda.cl (A.N); jjpaya@cst.upv.es (J.P.); vborrachero@cst.upv.es (M.V.B.); \\ jmmonzo@cst.upv.es (J.M.). \\ $\left(^{*}\right)$ corresponding author
}

\begin{abstract}
Some Chilean copper slag dumps from the nineteenth century still remain, without a proposed use that encourages recycling and reduces environmental impact. In this paper, the copper slag abandoned in landfills is proposed as a new building material. The slags studied were taken from Playa Negra and Púquios dumps, both located in the region of Atacama in northern Chile. Pozzolanic activity in lime and Portland cement systems, as well as the alkali activation in pastes with copper slag cured at different temperatures, was studied. The reactivity of the slag was measured using thermogravimetric analysis (TGA), scanning electron microscopy (SEM), X-ray diffraction (XRD), electrical conductivity and $\mathrm{pH}$ in aqueous suspension and Fourier Transform Infrared Spectroscopy (FTIR). Furthermore, copper slagPortland cement mortars with the substitution of $25 \%$ (by weight) of cement by copper slag and alkali-activated slag mortars cured at 20 and $65^{\circ} \mathrm{C}$ were made, to determine the compressive strength. The results indicate that the ancient copper slags studied have interesting binding properties for the construction sector.
\end{abstract}

Keywords: Copper slag; pozzolanic activity; alkali activation; geopolymer.

\section{Introduction}

Industrial slags are usually classified as ferrous and nonferrous slags, and may be used in the manufacture of new materials. Slags from extracting metal processes are conventionally considered as waste materials (Nazari and Sanjayan, 2015). In construction, copper slag (CS) is used in fillings, embankments, drainage, ballast, as aggregates in mortars, concrete (Thomas and Gupta, 2013; Mithun and Narasimhan, 2015) and asphalt mixtures (Hassan and Al-Jabri, 2011), as abrasive material (Kambham et al., 2007), as a cement substitute (Shi and Qian, 2000; Moura and Coutinho, 2004; Zain et al., 2004; Al-Jabri et al., 2006; Moura et al., 2007; Taha et al., 2007; Sánchez de Rojas et al., 2008; Brindha et al., 2010; Chew and Bharati, 2010; Brindha and Nagan, 2011; Najimi et al., 2011; Peyronnard and Benzaazoua, 2011), as raw material in the manufacture of Portland cement (PC) (Ariño and Mobasher, 1999; Chockalingam et al., 2013; 
García Medina et al., 2006; Gorai et al., 2003; Kosmatka et al., 2003) and also as binders in the manufacture of alkali-activated (AA) cements (Deja and Malolepszy, 1989, 1994; Shi et al., 2008; Iacobescu et al., 2013).

Regarding the use of CS aggregates, we can report that there are a few technical specifications (Federal Highway Administration Research and Technology. U.S. Department of Transportation, n.d.) and two standards governing their use as aggregates for concrete: one in Korea (Korean Standards Association, 2000) and one in Japan(Japan Mining Industry Association, 2003). The residue from the flotation tailings of CS has also been used in cement admixtures and cement manufacturing (Alp et al., 2008; Onuaguluchi, 2012).

According to the method of cooling employed, CS can be grouped into two types: air-cooled slags, which are black glass with low water absorption, and water-cooled slags which are amorphous, granulated and present greater water absorption capacity (Onuaguluchi, 2012). CS generated nowadays is composed "Fe (30-40\%), $\mathrm{SiO}_{2}$ (35-40\%), $\mathrm{Al}_{2} \mathrm{O}_{3}(\leq 10 \%), \mathrm{CaO}(\leq 10 \%)$ and $\mathrm{Cu}(0.5-2.1 \%) "$ (Gorai et al., 2003).

In Chile, there are CS dumps that were produced in the nineteenth century that have environmental effects on the soil (destruction of beaches and shoreline pollution) and landscape (visual pollution barriers in natural channels), as well as social (alteration of Historic Places) and economic (land use) impacts. Chilean law classifies these slags as non-hazardous waste (Ministerio de Salud de Chile, 2004). Often, "the statistical analysis provides a basis for predicting with high probability that the composition of the CS and their leachates will remain in the non-hazardous range" (Alter, 2005). Moreover, they can degrade over time, and may potentially be a source of toxic metals (Piatak et al., 2004). So far there has been no proposal to use former CS landfills and reduce these effects, or to use them as raw materials in the manufacture of mortars and concretes based on PC and/or AA cement.

The aim of this study is to determine the feasibility of using two CS produced in the nineteenth century, Playa Negra and Púquios, which are abandoned landfills located in the region of Atacama in Chile, as building materials. Pozzolanic activity in lime and Portland cement systems, as well as the AA in pastes with copper slag cured at different temperatures, was studied. Moreover, CS-PC mortars with the substitution of 25\% (by weight) of cement by $\mathrm{CS}$ and AA slag mortars cured at 20 and $65^{\circ} \mathrm{C}$ were made, to determine the compressive strength.

\section{Experimental}

\subsection{Materials}

CS samples of the nineteenth century, originating from the landfills Playa Negra (CS_PN) and Púquios (CS_PQ), both located in the region of Atacama in northern Chile, were used. The CS_PQ is located $150 \mathrm{~km}$ away from CS_PN. The PC used in cement pastes and mortars, is 
CEM I-52.5 R type according to EN 197-1 (UNE-EN 197-1:2011, 2011). The chemical composition of the slags and the PC used are shown in Table 1. In mortars CS/PC, standard sand (Normensand, Germany) was used, while in the AA mortars silica sand (Caolines Lapiedra, Valencia, Spain) was used, according to EN 196-1 standard (UNE-EN 196-1:2005, 2005). As an activator for the AA reaction, 98\% pure sodium hydroxide in pellet form (Panreac) and sodium silicate solution $\left(\mathrm{SiO}_{2}=28 \%, \mathrm{Na}_{2} \mathrm{O}=8 \%, \mathrm{H}_{2} \mathrm{O}=64 \%\right.$, by weight, Merck) were used. In the conductimetric method (Tashima et al., 2014), for the testing of pozzolanic reactivity, an aqueous suspension of calcium hydroxide powder was used (minimum 95\% purity, Panreac). In the manufacture of cement mortars and pastes, water from the Valencia city network and deionised water were used.

Table 1. Chemical composition of PC and CS (Wt. \%) and Density (g/cm3).

\begin{tabular}{llllllllllll}
\hline & $\mathbf{S i O}_{2}$ & $\mathbf{A l}_{2} \mathbf{O}_{3}$ & $\mathbf{F e}_{2} \mathbf{O}_{3}$ & $\mathbf{C a O}$ & $\mathbf{M g O}$ & $\mathbf{S O}_{3}$ & $\mathbf{K}_{2} \mathbf{O}$ & $\mathbf{N a}_{2} \mathbf{O}$ & $\mathbf{O t h e r}$ & $\mathbf{L O I}$ & $\begin{array}{l}\text { Densi } \\
\text { ty }\end{array}$ \\
\hline PC & 20.80 & 4.60 & 4.80 & 65.60 & 1.20 & 1.70 & 1.00 & 0.07 & 0.23 & 2.02 & 3.07 \\
CS_PN & 39.14 & 7.76 & 30.48 & 13.41 & 2.09 & 0.46 & 1.50 & 1.05 & 3.60 & $-2.11^{*}$ & 3.16 \\
CS_PQ & 38.33 & 8.17 & 20.40 & 26.10 & 2.14 & 0.26 & 0.78 & 0.64 & 3.59 & $-1.50^{*}$ & 2.96 \\
\hline \multicolumn{7}{r}{ * mass gain probably due to oxidation $\mathrm{FeO}$ and S ${ }^{2-}$ (sulphides) (Sánchez de Rojas et al., } &
\end{tabular}
2008).

The CS was first milled using a jaw crusher; after this, a ball mill with alumina balls that were $18 \mathrm{~mm}$ in diameter was used. Particle size distribution was determined using a laser diffraction granulometer (Mastersizer 2000, Malvern Instruments). The final average diameter for both milled CS samples was $15 \mu \mathrm{m}$ and $90 \%$ of particles were smaller than $40 \mu \mathrm{m}$ after 35 minutes grinding time. The particle size distribution curves of both ground forms of CS are shown in Fig. 1.

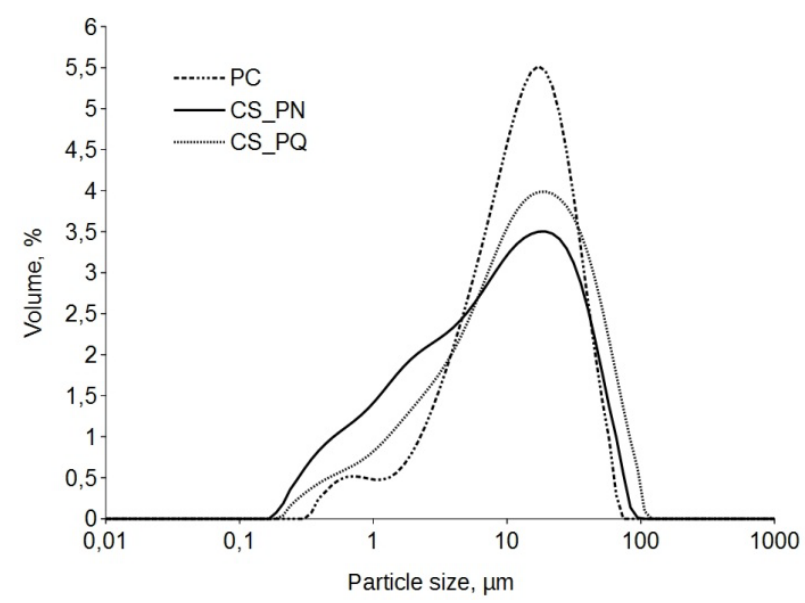

Fig. 1. Particle size distribution curve of PC and ground CS.

The CS chemical compositions were determined by X-ray fluorescence (XRF MAGIC PRO Philips, mod. PW2400) and are shown in Table 1. The results show that the two samples of CS contain a very significant amount of iron oxides and silica. The silica content of both samples is 
very similar; however, the iron oxide content is higher in the CS_PN. They also have a high content of $\mathrm{CaO}$, which may indicate their feasibility as a precursor material for alkali activation (Canfield et al., 2014). Moreover, it can be seen that the CaO content in CS_PQ is twice the content in CS_PN. The high content of $\mathrm{CaO}$ and $\mathrm{Fe}_{2} \mathrm{O}_{3}$ less, with respect to copper slag used in other studies (Gorai et al., 2003) is due to the contribution of fluxes such as silica and lime used during smelting. It is usual to add silica to capture separating copper iron during smelting, and lime gives flow properties within the furnace slag.

The X-ray diffraction (XRD, Brucker AXS D8 Advance) patterns were obtained using a Cu$\mathrm{K} \alpha$ radiation under conditions of $40 \mathrm{kV}$ and $20 \mathrm{~mA}$, in the range $2 \theta=5-70^{\circ}$. Fig. 2 shows that CS_PQ is fully amorphous; this is evidenced by the strong deviation of the baseline between 20 and $40^{\circ} 2 \Theta$ values. Only trace amounts of diopside type crystalline compounds, fayalite and clinoferrosilite were detected. Furthermore, the mineralogical CS_PN showed a structure that mainly consisted of diopside, magnetite and fayalite; clinoferrosilite was present to a lesser extent.

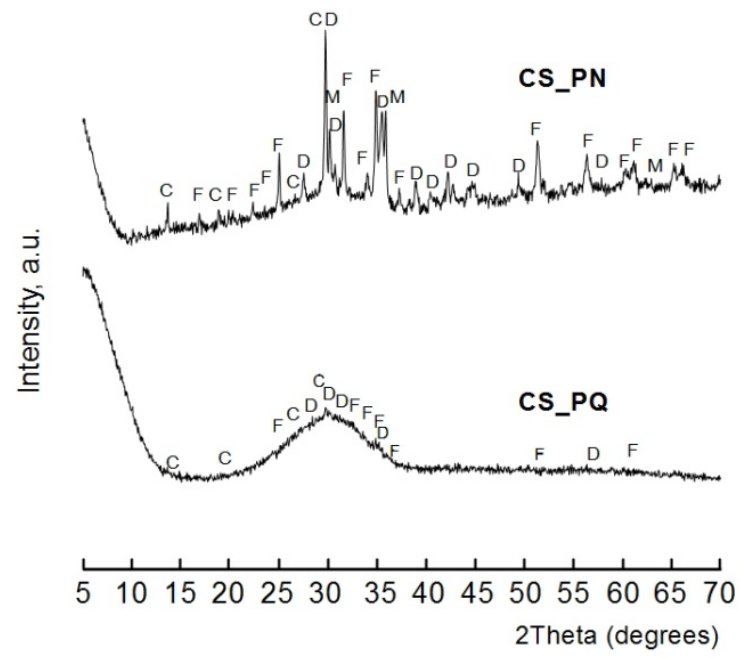

Fig. 2. X-ray diffractogram patterns of raw CS_PN and CS_PQ materials. D: Diopside (CaMgSiO 3 : PDFcard 190239); F: Fayalite ( $\mathrm{Fe}_{2} \mathrm{SiO}_{4}$ : PDFcard 340178); C: Clinoferrosilite ( $\mathrm{FeSiO}_{3}$ : PDFcard 170548); M: Magnetite $\left(\mathrm{Fe}_{3} \mathrm{O}_{4}\right.$ : PDFcard 190629).

Thermogravimetric analysis (TGA, Mettler-Toledo 850) of CS samples was carried out at ranges of $35-1000^{\circ} \mathrm{C}$ (alumina crucible), with the heating rate being $20^{\circ} \mathrm{C} / \mathrm{min}$ in air atmosphere. TG and DTG curves of CS_PN and CS_PQ samples are plotted in Fig. 3. In TGA curves, CS_PN and CS_PQ samples gain masses of 3.15 and 2.15\% respectively, probably due to the oxidation of Fe (II) compounds and sulphides S $^{2-}$ (Sánchez de Rojas et al., 2008). In the CS samples part of the mass gain could be due to fayalite oxidation according to the equation $\mathrm{Fe}_{2} \mathrm{SiO}_{4}+1 / 2 \mathrm{O}_{2} \rightarrow \alpha \mathrm{Fe}_{2} \mathrm{O}_{3}+\mathrm{SiO}_{2}$ (Gorai et al., 2003). 


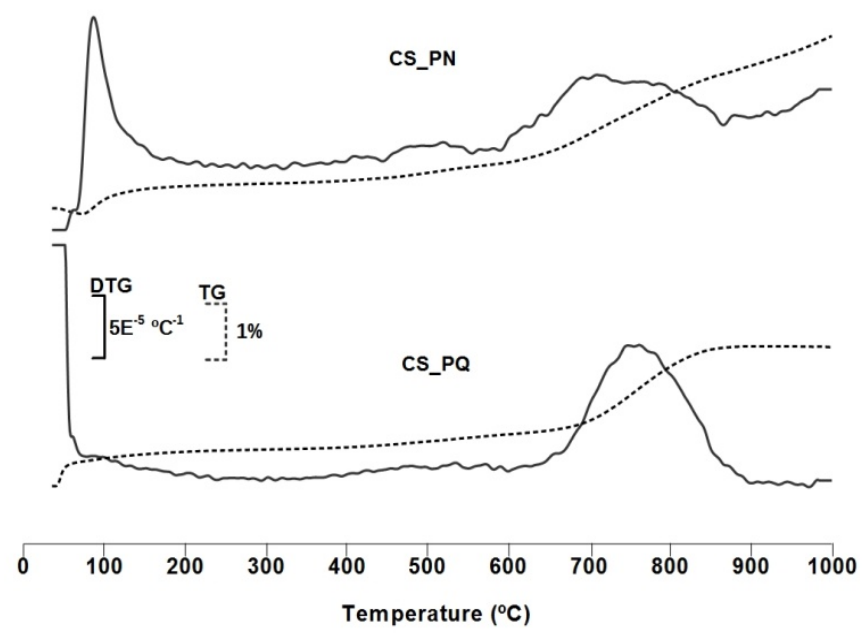

Fig. 3. TG and DTG curves for CS_PN and CS_PQ.

The samples were also evaluated by Fourier Transform Infrared Spectroscopy (FTIR Bruker Tensor 27 MIR, range of 7800-370 $\mathrm{cm}^{-1}$ ). The spectrum for CS PQ of Fig. 4 shows peaks in the range $3750-3600 \mathrm{~cm}^{-1}$, which are associated with $\mathrm{OH}^{-}$valence vibrations, both symmetric and asymmetric (Darder et al., 2014). Furthermore, for both samples, the peaks in the range 1000$850 \mathrm{~cm}^{-1}$ can be attributed to Si-O asymmetric stretching vibrations of the $\mathrm{v}_{3}$ mode in $\mathrm{SiO}_{4}$ (Mihailova and Mehandjiev, 2010). In the range $450-500 \mathrm{~cm}^{-1}$, vibrations associated to $v_{4}(\mathrm{O}-\mathrm{Si}$ O) deformation can be observed (Fernández-Jiménez, 2000). In general, the FTIR spectra show that both slags exhibit vibrations primarily associated with Si-O bonds.

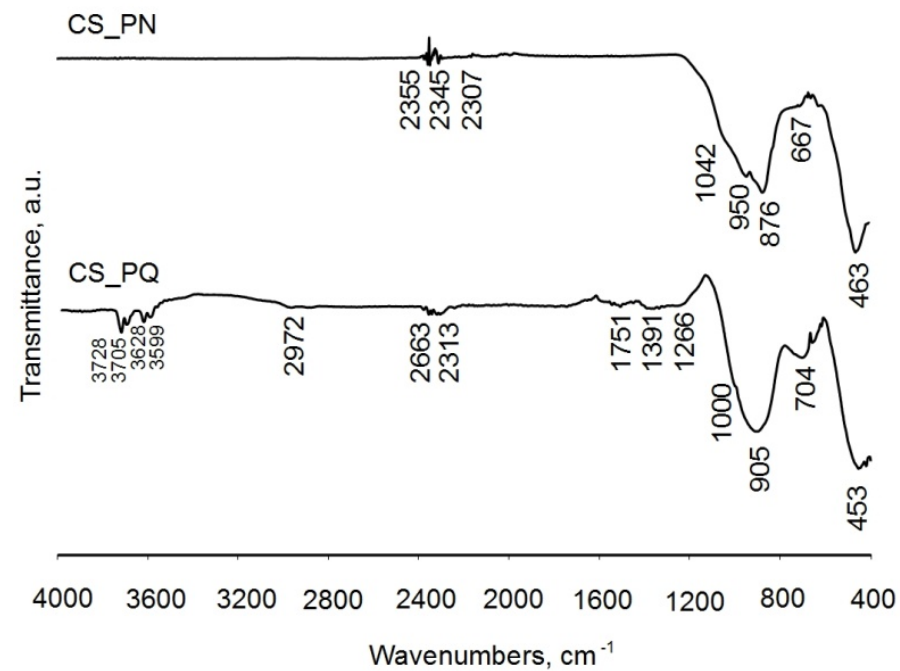

Fig. 4. FTIR spectra of CS_PQ and CS_PN samples.

Microscopic analysis and morphology of CS samples were studied using scanning electron microscopy (SEM, JEOL-JSM-6300) equipped with energy dispersive X-ray spectroscopy (EDX) and using a voltage of $20 \mathrm{kV}$ for imaging. Fig. 5 shows that both ground CS samples presented crushed particles with angular shapes. 


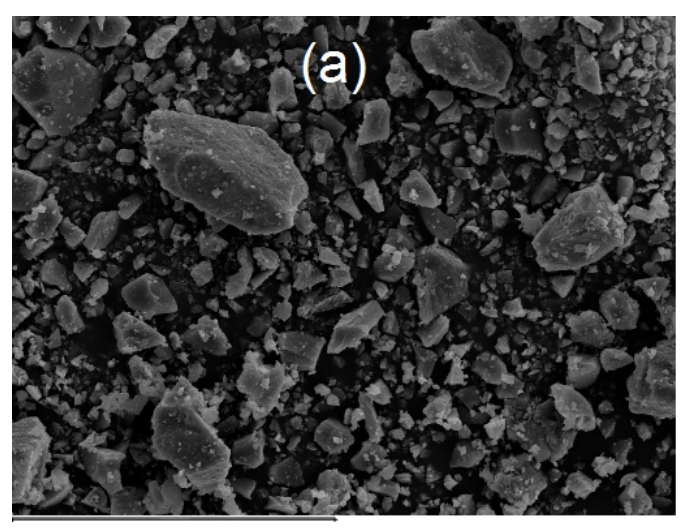

$60 \mu \mathrm{m}$

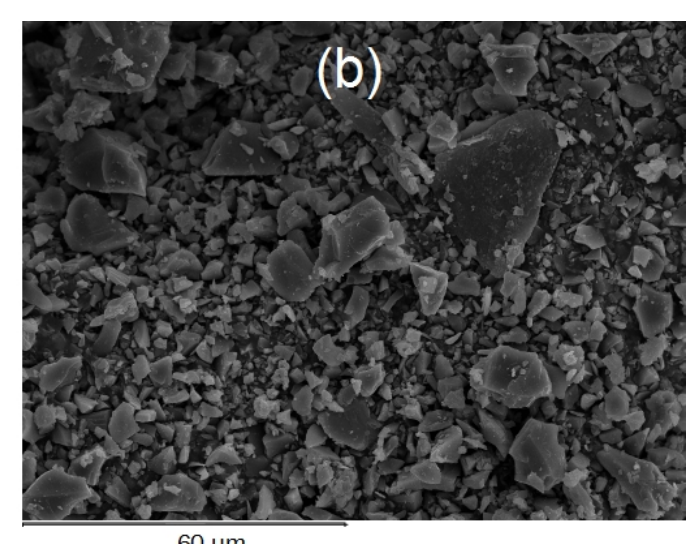

$60 \mu \mathrm{m}$

Fig. 5. SEM micrographs of ground CS: a) CS_PN; b) CS_PQ.

\subsection{Procedures}

\subsubsection{Copper slag alkali-activated cement pastes}

CS AA cement pastes were prepared by mixing CS with an alkaline activator solution (by weight). Mixes are coded as '25/5/1.45', where 25 is the amount of water per $100 \mathrm{~g}$ of CS, 5 is the molality of $\mathrm{Na}^{+}$in the activating solution and 1.45 is the $\mathrm{SiO}_{2} / \mathrm{Na}_{2} \mathrm{O}$ molar ratio in the activating solution. As shown in Table 2 a set of pastes samples were cured at $20^{\circ} \mathrm{C}$ and $95 \% \mathrm{RH}$ for 7 and 28 days and other set of pastes at $65^{\circ} \mathrm{C}$ in thermostatically controlled bath for 1,3 and 7 days. The alkaline activator solution was prepared by dissolving $\mathrm{NaOH}$ pellets in water and adding the required amount of sodium silicate solution. Paste samples were milled, washed with acetone to stop the reaction process, and stored sealed until characterisation. TGA studies on AA pastes were carried out using an sealed aluminum crucibles with a pinhole lid, from $35-600^{\circ} \mathrm{C}$ at $10^{\circ} \mathrm{C} /$ min heating rate in air atmosphere. Microscopic analysis and morphology of AA pastes were studied using SEM with a voltage of $20 \mathrm{kV}$ for imaging.

Table 2. Alkali-activated cement pastes nomenclature.

\begin{tabular}{lll}
\hline Sample & Curing time, days & Curing temperature, ${ }^{\mathbf{0}} \mathbf{C}$ \\
\hline CS_PN AA20 & 7 and 28 & 20 \\
CS_PN AA65 & 1,3 and 7 & 65 \\
CS_PQ AA20 & 7 and 28 & 20 \\
CS_PQ AA65 & 1,3 and 7 & 65 \\
\hline
\end{tabular}

\subsubsection{Portland cement mortars containing CS}

Mortar cubes of $40 \times 40 \times 40 \mathrm{~mm}$ replacing $25 \%$ (in weight) of PC by CS ( PC/CS_PN and PC/CS_PQ mortars) were manufactured and tested in compression at ages of 28 and 90 days. PC mortars were also made as control samples. In all mortars, the water/binder ratio (w/b) was 0.44 (the binder being the sum of PC and CS). The mixing procedure was carried out according UNE-EN 196-1(UNE-EN 196-1:2005, 2005). Mortars were cured at $20^{\circ} \mathrm{C}$ under a saturated solution of calcium hydroxide. The mortar compositions are summarised in Table 3. 
Table 3. Mortar composition nomenclature.

\begin{tabular}{lllll}
\hline & PC & CS & $\begin{array}{l}\text { Sand } \\
\text { g }\end{array}$ & w/b \\
\cline { 2 - 5 } Mortar control & 450.0 & 0 & 1350 & 0.44 \\
Mortar PC/CS_PN & 337.5 & 112.5 & 1350 & 0.44 \\
Mortar PC/CS_PQ & 337.5 & 112.5 & 1350 & 0.44 \\
\hline
\end{tabular}

\subsubsection{Copper slag alkali-activated cement mortars}

AA cement mortar cubes with a size of $40 \times 40 \times 40 \mathrm{~mm}$ were manufactured. A set of mortars samples was were cured in a chamber at $20^{\circ} \mathrm{C}$ for 7,28 and 90 days and other set of mortars were cured in a thermostatically controlled bath at $65^{\circ} \mathrm{C}$ for 3,7 and 28 days. For each samples set, 450 grams of copper slag and 1350 grams of sand were used. The molar ratio of the alkaline activators $\mathrm{SiO}_{2} / \mathrm{Na}_{2} \mathrm{O}$ was 1.45 and the w/CS was 0.30 . For analysis of the results of mortar strength, the approach suggested in UNE 83485:1996 EX (UNE 83485:1996 EX, 1996) was applied.

\subsubsection{Conductimetric method for pozzolanic reactivity evaluation}

To assess the pozzolanic reactivity of the slag, the Tashima method was used (Tashima et al., 2014). This method consists of measuring the $\mathrm{pH}$ and electrical conductivity evolution for 7 days of different mixtures of calcium hydroxide-saturated aqueous suspensions and pozzolan (CH:pozzolan in mass ratio, one gram total in $50 \mathrm{ml}$ of desionized water for each ratio) at different temperatures: 40,50 and $60^{\circ} \mathrm{C}$.

A pH meter Crison micro PH2001 and an electrical conductivity meter Crison micro CM2201 were used to measure the pozzolanic reaction progress. A shaking water bath JULABO- SW22 working in the temperature range of $20-99.9^{\circ} \mathrm{C}$ was used to control the test temperature. At the beginning of the test, all of the prepared suspensions were saturated in calcium hydroxide with an excess of calcium hydroxide in the solid state. During the testing period, a reduction in the $\mathrm{pH}$ and electrical conductivity values can be observed for some of the suspensions, indicating the unsaturated state of the suspension with respect to calcium hydroxide due to the pozzolanic reaction progress. The reductions in $\mathrm{pH}$ and electrical conductivity values are due to the reaction of dissolved $\mathrm{Ca}^{+2}$ and $\mathrm{OH}^{-}$ions with pozzolan particles to form stable and insoluble products (Luxán et al., 1989). The presence of calcium hydroxide in the solid state maintained the concentration of dissolved $\mathrm{Ca}(\mathrm{OH})_{2}$ at an approximately constant level in the suspension (saturated system) and, when the ions dissolved in the solution are consumed, solubilisation of calcium hydroxide took place quickly, again reaching saturation of the solution. The solubilisation process is finished when calcium hydroxide in solid state is exhausted. From this moment (unsaturated system), when the $\mathrm{CH}$ in solid state is totally dissolved, a reduction on $\mathrm{pH}$ and electrical conductivity values can be detected, indicating the beginning of the unsaturation step. In this study, different $\mathrm{CH}$ :CS mixes, 
1:9, 2:8, 3:7, 4:6 and 5:5 (mass ratio, one gram total in $50 \mathrm{ml}$ of desionized water for each ratio) for 40,50 and $60^{\circ} \mathrm{C}$, were tested.

\section{Results and discussion}

\subsection{Alkali-activated copper slag cement pastes}

In Fig. 6, XRD patterns for AA pastes cured at $20^{\circ} \mathrm{C}$ for 28 days are shown. The XRD pattern for CS_PN AA paste (Fig. 6a) showed the same peaks as those observed for the original slag. This means that the crystalline products present in the original slag did not evolve during the alkali activation reaction. Additionally, no evidence of the zeolitic phase formation was found. The reaction products formed were amorphous. CS_PQ slag did not show any crystallized products and after alkali activation no changes were noticed (Fig. 6b); again, the reaction compounds were amorphous and there were no zeolitic phases. AA pastes cured at $65^{\circ} \mathrm{C}$ for 7 curing days yielded very similar XRD patterns to those obtained at $20^{\circ} \mathrm{C}$ for 28 days: this means that the curing temperature in the $20-65^{\circ} \mathrm{C}$ range did not significantly affect the reaction products.
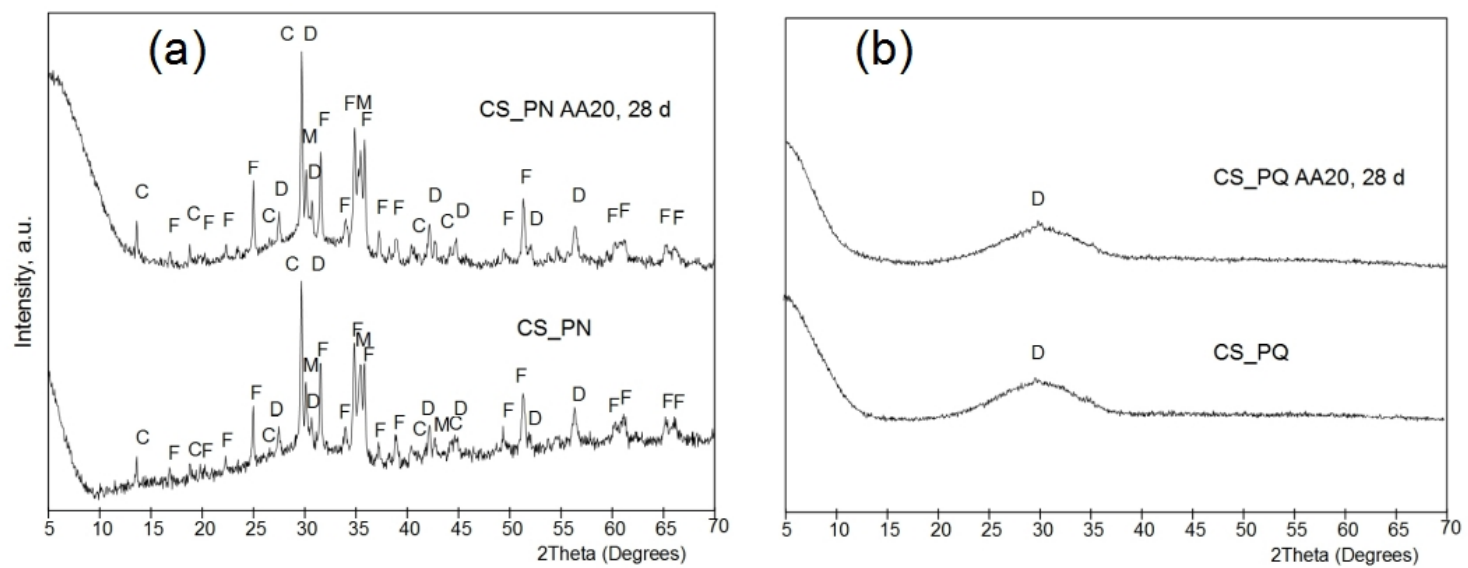

Fig. 6. X-ray diffractograms of CS and AA pastes after curing at $20^{\circ} \mathrm{C}$ for 28 days.

(a) CS_PN and (b) CS_PQ.

FTIR analysis of the AA pastes is shown in Fig. 7. In general, the presence of bands in the range $3750-3600 \mathrm{~cm}^{-1}$ can be observed, attributed to valence vibrations $\mathrm{OH}$, asymmetric and symmetric (Darder et al., 2014); the presence of OH groups is related to the hydration products. The band at the $1450-1380 \mathrm{~cm}^{-1}$ is attributed to O-C-O deformation vibration in carbonates due to carbonation products (may be an interaction of air and alkali hydroxide took place). Bands in the range $1000-850 \mathrm{~cm}^{-1}$ are attributed to the polymerisation process of $\mathrm{SiO}_{4}$ - linking tetrahedra. For CS_PN slag, the peak at $876 \mathrm{~cm}^{-1}$ was maintained during the reaction progress (both at 20 and $65^{\circ} \mathrm{C}$ ), and was attributed to crystalline matter (fayalite, diopside, clinoferrite); however, an increase in intensity for the peak at $950 \mathrm{~cm}^{-1}$ was produced: this behaviour was due to the formation of new Si-O-Si bonds from the reaction progress. For CS_PQ slag, the broad peak 
centred at $905 \mathrm{~cm}^{-1}$ evolved with alkali activation; thus, a higher energy peak (about 950-960 $\mathrm{cm}^{-1}$ ) was produced for cured materials. Bands in the range $445-460 \mathrm{~cm}^{-1}$ were attributed to bending vibrations of Si-O/Al-O (Nath and Kumar, 2013; Komnitsas et al., 2013) which were present for all cured materials.

(a)

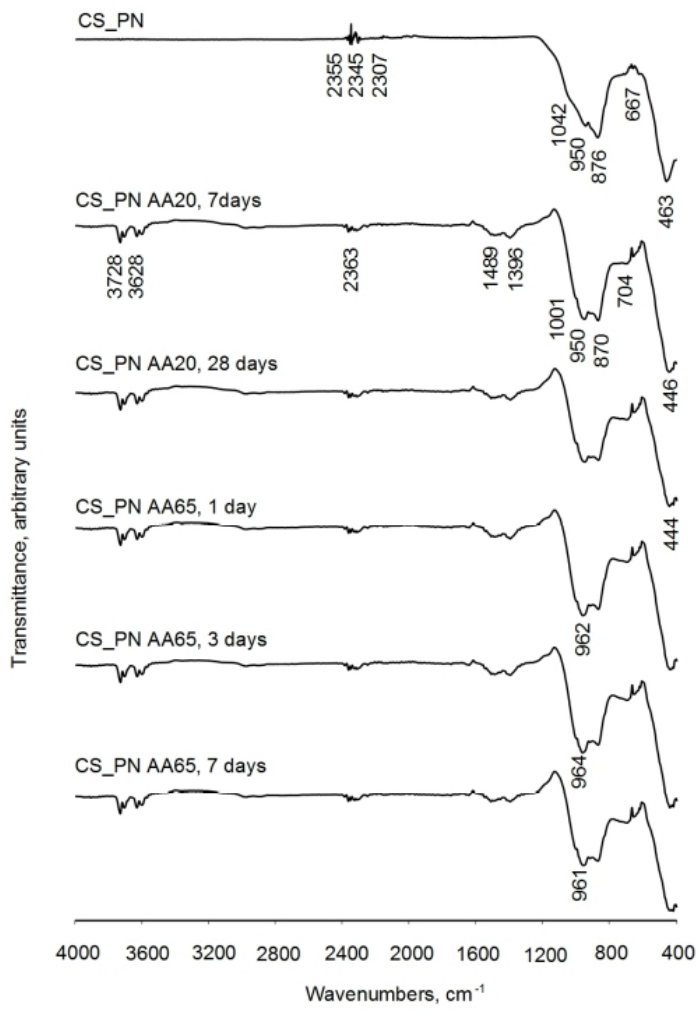

(b)

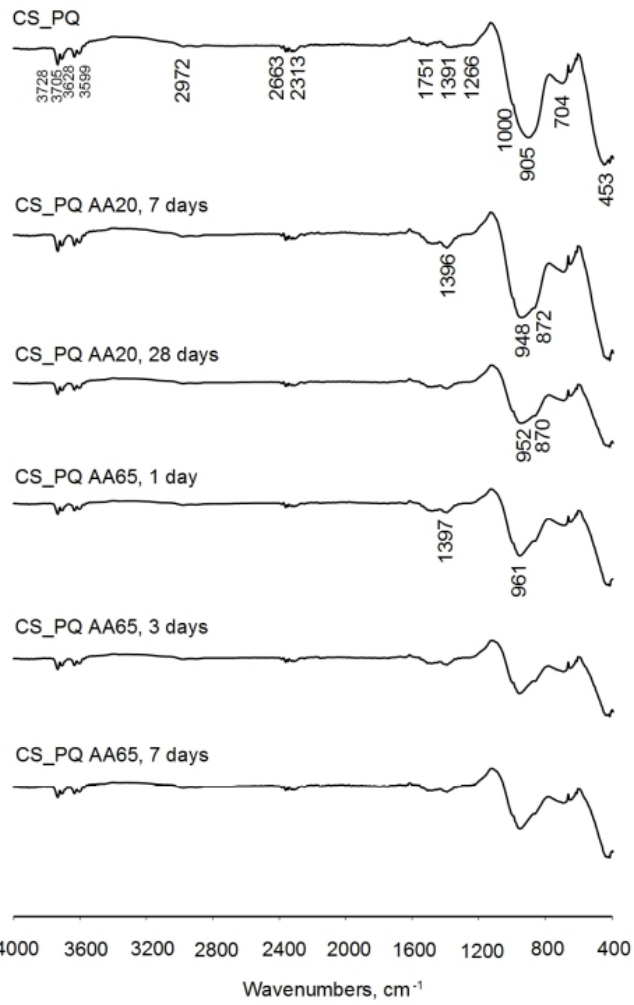

Fig. 7. (a) FTIR CS_PN and (b) FTIR CS_PQ, alkali activated slags cement pastes.

Table 4 shows thermogravimetric analysis data, summarising the total weight loss (TG, 850 Mettler-Toledo from $35-600^{\circ} \mathrm{C}$ range, using sealed pin holed aluminium crucibles at a heating rate of $10^{\circ} \mathrm{C} \mathrm{min}^{-1}$ ) of AA pastes cured at $65^{\circ} \mathrm{C}$ and $20^{\circ} \mathrm{C}$. As observed in Fig. 8, all paste samples showed a DTG peak in the $129-148^{\circ} \mathrm{C}$ range, typical of AA gels. This loss of weight is attributed to chemically bond water and hydroxyl groups present in these samples (Tashima et al., 2012). In general, an increase in the total weight loss of pastes occurred when curing times increase for 65 and $20^{\circ} \mathrm{C}$. This is evidence of progress of the AA process. When both slags are compared, slightly further progress of the reaction in the CS_PQ AA, was generally observed, although the differences were more pronounced in the experiments carried out at $65^{\circ} \mathrm{C}$.

Table 4. Thermogravimetric total loss of weight (\%) in AA CS pastes cured at 65 and $20^{\circ} \mathrm{C}$.

\begin{tabular}{llllll}
\hline Curing temperature & $65^{\circ} \mathrm{C}$ & & & $20^{\circ} \mathrm{C}$ & \\
\hline Cure time & 1 day & 3 days & 7 days & 7 days & 28 days \\
\hline CS_PN & 6.01 & 8.27 & 7.81 & 4.67 & 6.25 \\
CS_PQ & 7.67 & 8.84 & 9.19 & 4.03 & 6.45 \\
\hline
\end{tabular}


SEM micrographs of AA CS cements are shown in Fig. 9. It can be seen that the CS-reacted product created a matrix with a compacted appearance. However, it appears to be less porous when cured at a temperature of $65^{\circ} \mathrm{C}$. When both slags are compared, lower porosity can be observed in CS_PQ for both curing temperatures. This corroborates the reactivity of CS, as evidenced in thermogravimetry data shown in Table 4 and compressive strength development in Fig. 11.
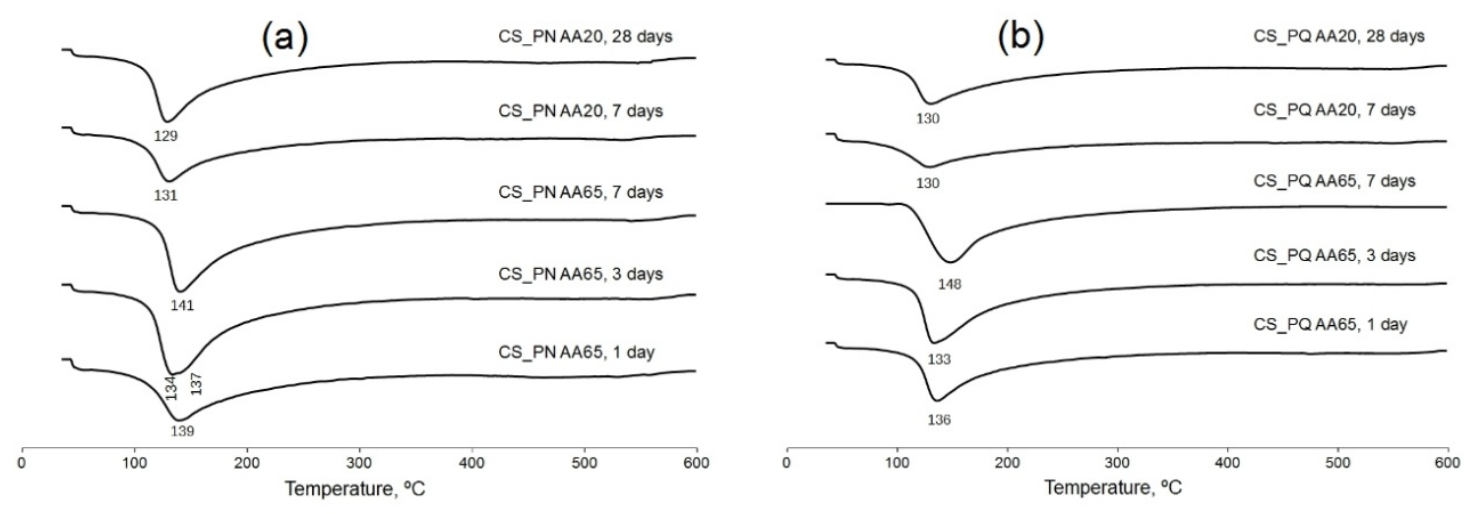

Fig. 8. Differential thermogravimetric curves for alkali-activated CS pastes (a) CS_PN; (b) CS_PQ.
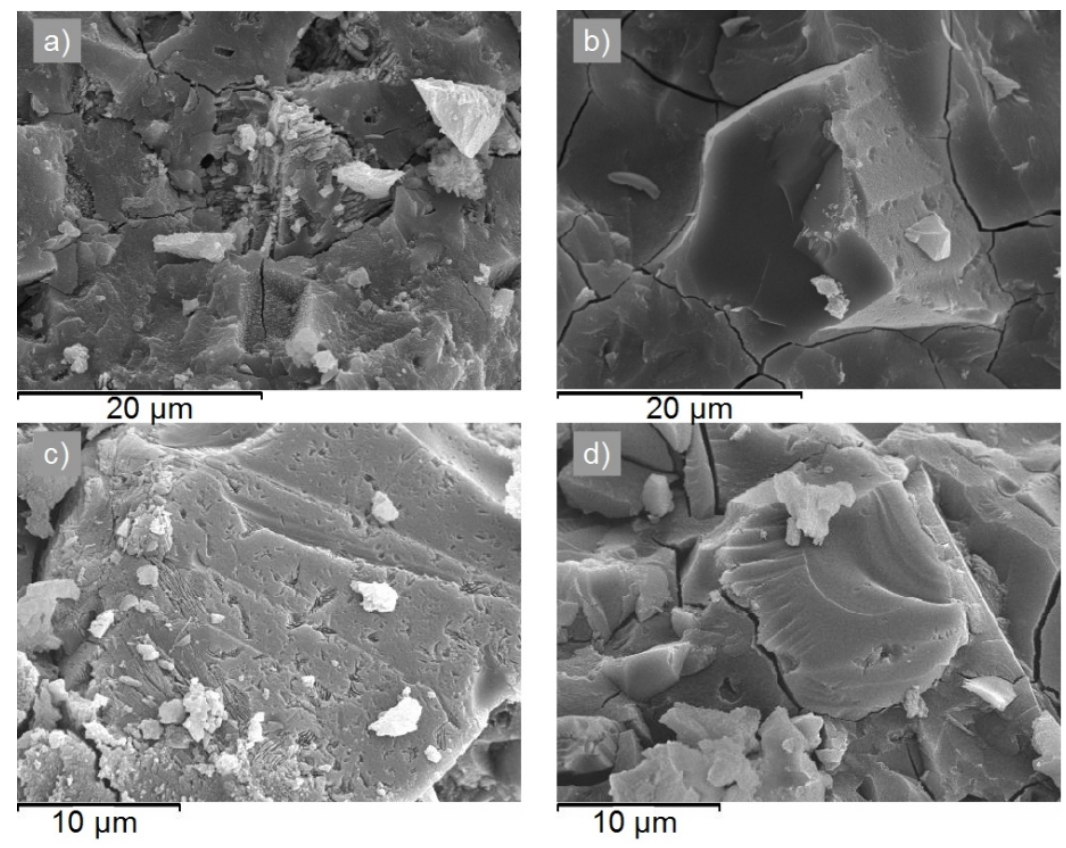

Fig. 9. Scanning electron microscope images of CS: a) CS_PN AA65 cured for 7 days; b) CS_PQ AA65 cured for 7 days; c) CS_PN AA20 cured for 28; and d) CS_PQ AA20 cured for 28 days.

\subsection{Mortars}

\subsubsection{Copper slag in Portland cement mortars}

Compressive strengths for control mortars and mortar specimens with 25\% replacement of PC by CS_PN or CS_PQ are shown in Fig. 10. Two control mortars were used, one for each 
slag mortar, because they were prepared on different dates. In general, control mortar strength was higher than CS-containing mortars. The strength activity ratio (SAR) satisfactorily complied with the requirements of the European standard EN 450-1:2013 (UNE-EN 450$1: 2013,2013)$ for fly ashes. This standard requires an SAR of $75 \%$ for 28 days curing time and 85\% for the 90 days of curing time. CS_PQ greater reactivity in the 90 days curing is observed.

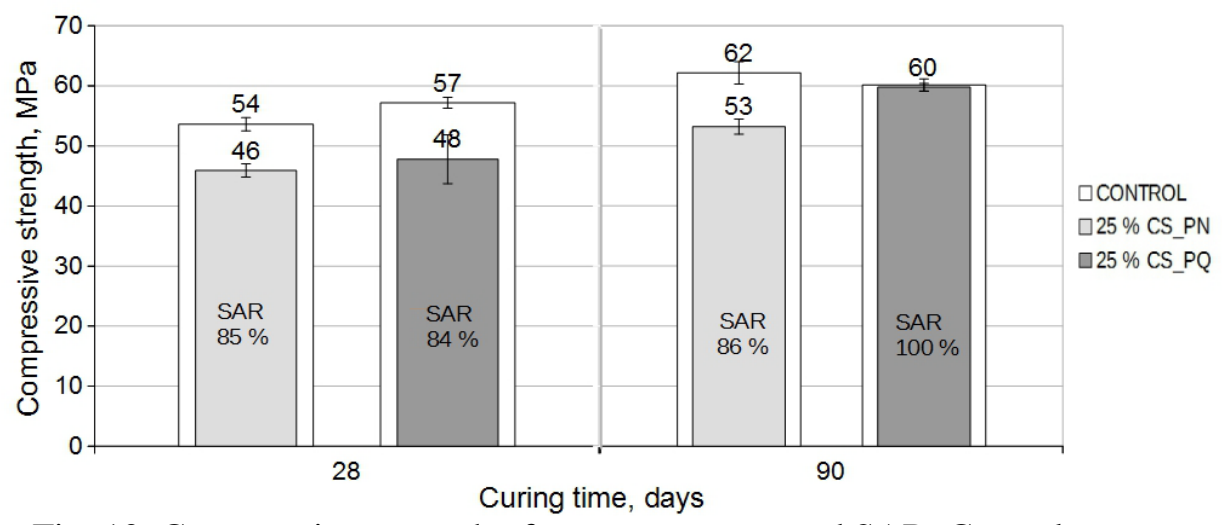

Fig. 10. Compressive strength of cement mortars and SAR. Control mortar and CS containing mortars with the replacement of $25 \%$ at curing ages of 28 and 90 days.

For an approach the cementing efficiency ( $k$-factor) of the CS in mortars replacing a PC with 25\% CS for ages 28 and 90 days it has been used Bolomey's model.The k-factor represents the amount of cement that can be replaced in a paste or mortar pozzolan to obtain the same value of mechanical strength and can be calculated using Eq. 1.

$$
\boldsymbol{k}=\frac{\left(\frac{\sigma}{\mathrm{a}}-\mathbf{b}\right) \mathbf{w}-\mathbf{c}}{\mathbf{p}}
$$

Where $\sigma$ is the compressive strength, $a$ and $b$ are two constant calculated from compressive strength values for mortars with different $w / c$ ratios and $p$ is the amount of added pozzolan. The $k$-factors are shown in Table 5.

Table 5. k-factors, a and b for mortars containing the replacement of 25\% of CS.

\begin{tabular}{ccccccc}
\hline Sample & \multicolumn{3}{c}{ 28 days } & \multicolumn{3}{c}{$\mathbf{9 0}$ days } \\
\hline \multirow{2}{*}{ 25\% CS_PN } & $\mathrm{a}$ & $\mathrm{b}$ & $\mathrm{k}$ & $\mathrm{a}$ & $\mathrm{b}$ & $\mathrm{k}$ \\
\cline { 2 - 7 } 23.29 & 0.20 & 0.19 & 25.87 & 0.18 & 0.36 \\
25 CS_PQ & 23.29 & 0.20 & 0.35 & 25.87 & 0.18 & 0.85 \\
\hline
\end{tabular}

\subsubsection{Copper slag alkali-activated cement mortars.}

The results of compressive strength test on AA CS mortars are shown in Fig. 11. The results of AA pastes are in agreement with those obtained for the compressive strength of AA mortars, wherein the compressive strength of CS_PQ mortars was substantially higher than those made with CS_PN (see Fig. 11). Data were obtained after 7, 28 and 90 days curing temperature of $20^{\circ} \mathrm{C}$, and after 3 and 7 days curing at $65^{\circ} \mathrm{C}$. An increase in compressive strength with curing 
time can be observed for both slags and curing temperatures. In all cases, CS_PQ mortars presented higher compressive strength than CS_PN mortars, although this difference decreased when curing temperature or curing time increased. CS_PQ AA mortar shown a higher strength development at early ages and CS_PN shown a better strength development for longer curing age or for higher curing temperature. In the future, it would be interesting to design experiments with longer curing times to check whether compressive strengths of CS_PQ and CS_PN tend to equalize.

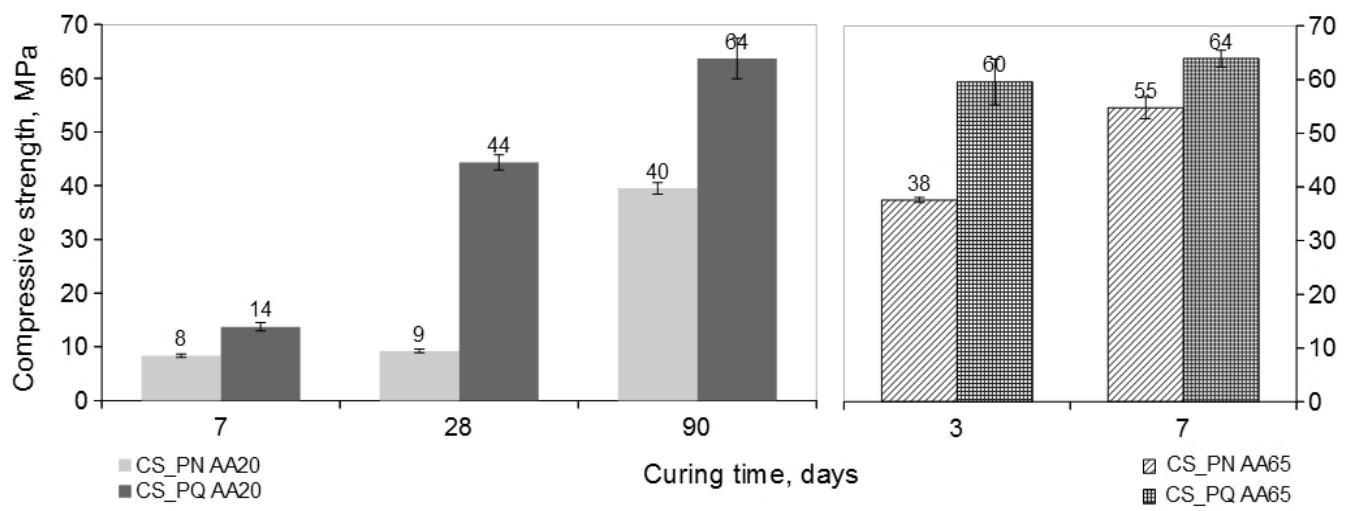

Fig. 11. Influence of curing time and curing temperature on compressive strength of CS AA mortars.

Higher compressive strength in CS_PQ mortars can be explained by taking into account the higher reactivity of CS_PQ, as evidenced in SEM studies. TG total loss of weight percentage for CS_PQ AA65 paste was slightly higher than CS_PN AA65 paste (see Table 4 and Fig. 7). The microstructure of CS_PQ AA paste is less porous for both curing temperatures (see Fig. 9). The greatest CS_PQ AA reactivity is probably related to the more amorphous character (see Fig. 2) which promotes the dissolution of the silica and alumina in the alkaline environment favouring AA reaction. It should be highlighted that mortars made with CS_PQ AA reached a compressive strength of $64 \mathrm{MPa}$ at 90 days of curing at $20^{\circ} \mathrm{C}$. Similar compressive strengths for mortars cured for 3 days at $65^{\circ} \mathrm{C}$ and mortars cured for 90 days at $20^{\circ} \mathrm{C}$ temperature were obtained. 


\subsection{Conductimetric method for pozzolanic reactivity evaluation}

At 40 and $50^{\circ} \mathrm{C}$ results in loss of conductivity in both slags are studied below $30 \%$, except the 1:9 and 2:8 mixtures to $60^{\circ} \mathrm{C}$. Therefore of no interest for comparison of materials.

At $60^{\circ} \mathrm{C}$, the $1: 9$ suspension showed that the maximum electrical loss conductivity (LC) at 168 hours of testing was $83 \%$ and 40\%, respectively, for CS_PN and CS_PQ. However, testing temperatures of 40 and $50^{\circ} \mathrm{C}$ deliver results below the line loss of $30 \%$ conductivity. Moreover, the variation in the $\mathrm{pH}$ of the 1:9 and 2:8 suspensions was not significant. Fig. 12 shows the variation of LC 1:9 and 2:8 suspensions at $60^{\circ} \mathrm{C}$. According to Tashima et al. (2014), the unsaturation time that is associated with the $\mathrm{LC}(\%)=30 \%$ could be used to assess the pozzolanic reactivity. Tashima et al. (2014) proposed three different zones, as shown Fig. 13: Zone 1 for low reactive pozzolans, Zone 2 for medium reactivity of the pozzolans and Zone 3 for highly reactive pozzolans. After evaluation of the CS, as shown Fig. 13, the mineral admixtures can be classified as low reactive pozzolanic materials. The suspensions 2:8 for CS_PN and CS_PQ reached unsaturation with a loss of conductivity of $30 \%$ at $74 \mathrm{~h}$ and $156 \mathrm{~h}$, respectively.

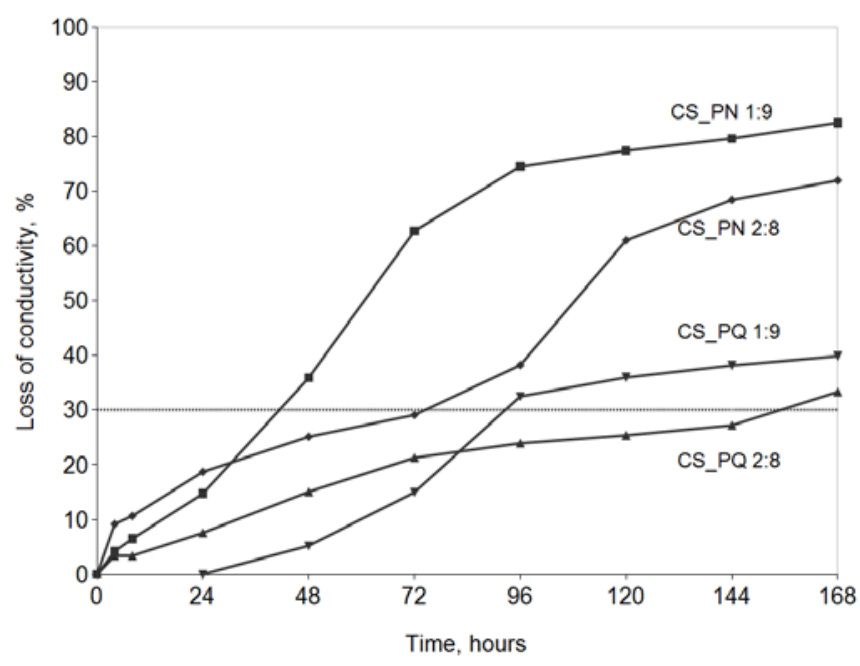

Fig. 12. Loss of electrical conductivity for $\mathrm{CH}$ : CS, 1:9 and 2:8 suspensions, test temperature of $60^{\circ} \mathrm{C}$.

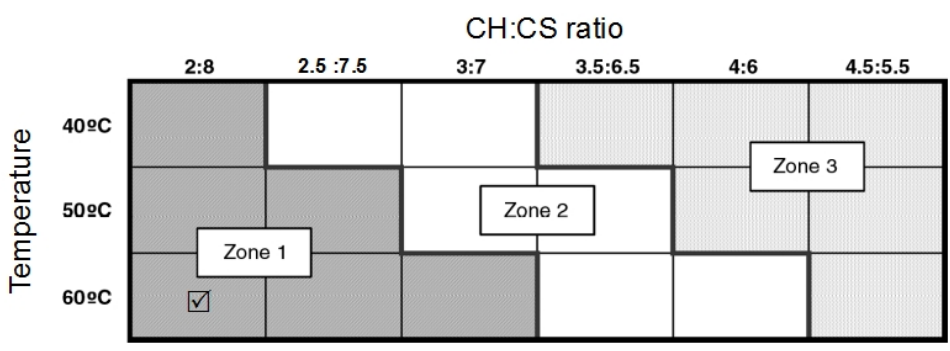

Fig. 13. Template for classification of pozzolan reactivity (Adapted from Tashima et al., 2014).

\section{Conclusions}

Both ancient CS (CS_PQ and CS_PN, in Chile) studied by means of the electrical conductimetric method for pozzolanic reactivity assessment can be classified as low reactive 
pozzolanic materials. Nevertheless, the strength activity ratio (SAR) in PC mortars in which $25 \%$ of the binder is CS results agree with the requirements of the European standard EN 450-1 for fly ashes. The highest reactivity of CS_PQ at 90 days agrees with the higher amorphous character of the sample shown in the X-ray diffraction pattern. CS AA pastes showed a DTG peak between 129 and $148^{\circ} \mathrm{C}$, which is typical for AA gels. In general, an increase in the total weight loss for AA pastes occurs when curing times and curing temperature increase, providing evidence of the progression of the AA reaction. Again, reaction progress of AA for CS_PQ was slightly higher than for CS_PN. These results are in agreement with those obtained for the compressive strength of AA mortars, wherein the compressive strength of CS_PQ mortars was substantially higher than those reported with the CS_PN. Probably, the greatest CS_PQ reactivity is related to the higher amorphous phase content, which facilitates the dissolution of the silica and alumina in the alkaline environment, favouring reaction with the alkaline solution. In accordance with the results, we can finally conclude that the studied ancient CS could be used successfully in PC and AA matrices, contributing to solving the environmental problem of the disposal of this waste, which has accumulated in large amounts in Chilean landfills.

\section{Acknowledgements}

We thank the Universidad de Atacama, Chile (Project FIC-ECO: "Using abandoned copper slag deposits, as a new building material") for facilitating copper slag samples for this research.

\section{References}

This aspect is briefly discussed in Section 2.1. Al-Jabri, K.S., Taha, R.A., Al-Hashmi, A., AlHarthy, A.S., 2006. Effect of copper slag and cement by-pass dust addition on mechanical properties of concrete. Construction and Building Materials 20, 322-331. doi:10.1016/j.conbuildmat.2005.01.020

Alp, İ., Deveci, H., Süngün, H., 2008. Utilization of flotation wastes of copper slag as raw material in cement production. Journal of Hazardous Materials 159, 390-395. doi:10.1016/j.jhazmat.2008.02.056

Alter, H., 2005. The composition and environmental hazard of copper slags in the context of the Basel Convention. Resources, Conservation and Recycling 43, 353-360. doi:10.1016/j.resconrec.2004.05.005

Ariño, A.M., Mobasher, B., 1999. Effect of ground copper slag on strength and toughness of cementitious mixes. ACI Materials Journal 96, 68-73.

Brindha, D., Baskaran, T., Nagan, S., 2010. Assessment of Corrosion and Durability Characteristics of Copper Slag Admixed Concrete. International Journal of Civil \& Structural Engineering 1, 192-210.

Brindha, D., Nagan, S., 2011. Durability studies on copper slag admixed concrete. Asian Journal of Civil Engineering ( Building and Housing) 12, 563-578. 
Canfield, G., Eichler, J., Griffith, K., Hearn, J., 2014. The role of calcium in blended fly ash geopolymers. Journal of Materials Science 49, 5922-5933. doi:10.1007/s10853-014-8307$\mathrm{Z}$

Chew, S.H., Bharati, S.K., 2010. Use of Recycled Copper Slag in Cement-Treated Singapore Marine Clay, in: Chen, Y., Zhan, L., Tang, X. (Eds.), . Springer Berlin Heidelberg, Hangzhou, China, pp. 705-710.

Chockalingam, M., Jayganesh, D., Vijayaraghavan, J., Jegan, J., 2013. Scope for reuse of copper slag in concrete- A review. .International Journal of Civil Engineering \& Technology 4, 89-100.

Darder, M., Gonzalez-Alfaro, Y., Aranda, P., Ruiz-Hitzky, E., 2014. Silicate-based multifunctional nanostructured materials with magnetite and Prussian blue: application to cesium uptake. RSC Advances 4, 35415-35421. doi:10.1039/C4RA06023G

Deja, J., Malolepszy, J., 1994. Long term resistance of alkali-activated slag mortars to chloride solution, in: Proc. Third CANMET/ACI Int. Conf. on Durability of Concrete, Nice, France, American Concrete Institute. pp. 657-671.

Deja, J., Malolepszy, J., 1989. Resistance of Alkali-Activated Slag Mortars to Chloride Solution, in: Third International Conference Proceedings. Fly Ash, Silica Fume, Slag, and Natural Pozzolans in Concrete, Trondheim, Noruega. American Concrete Institute, pp. 1547-1563.

Fernández-Jiménez, A., 2000. Cementos de escorias activadas alcalinamente: influencia de las variables y modelización del proceso. Madrid.

García Medina, L.E., Orrantia Borunda, E., Aguilar Elguézabal, A., 2006. Uso de la escoria de cobre en el proceso de fabricación de clínker para cemento Pórtland. Materiales de Construcción 56, 31-40.

Gorai, B., Jana, R.K., Premchand, 2003. Characteristics and utilization of copper slag-a review. Resources, Conservation and Recycling 39, 299-313. doi:10.1016/S09213449(02)00171-4

Hassan, H., Al-Jabri, K., 2011. Laboratory Evaluation of Hot-Mix Asphalt Concrete Containing Copper Slag Aggregate. Journal of Materials in Civil Engineering (ASCE) 23, 879-885.

Iacobescu, R.I., Geens, T., Jones, P.T., Blanpain, B., Pontikes, Y., 2013. Influence of curing condition on the physico-mechanical properties and leaching of inorganic polymers made from quenched fayalite-rich slag, in: 2nd International Conference. Braga, Portugal, pp. 341-346.

Kambham, K., Sangameswaran, S., Datar, S.R., Kura, B., 2007. Copper slag: optimization of productivity and consumption for cleaner production in dry abrasive blasting. Journal of Cleaner Production 15, 465-473. doi:doi: DOI: 10.1016/j.jclepro.2005.11.024

Komnitsas, K., Zaharaki, D., Bartzas, G., 2013. Effect of sulphate and nitrate anions on heavy metal immobilization in ferronickel slag geopolymers. Geopolymers: a new and smart way for a sustainable development 73, 103-109. doi:10.1016/j.clay.2012.09.018 
Kosmatka, S., Kerkhoff, B., Panarese, W., 2003. Design and Control of Concrete Mixtures, EB001, 14 th. ed. Portland Cement Association, Skokie, Illinois, USA.

Luxán, M.P., Madruga, F., Saavedra, J., 1989. Rapid evaluation of pozzolanic activity of natural products by conductivity measurement. Cement and Concrete Research 19, 63-68. doi:10.1016/0008-8846(89)90066-5

Mihailova, I., Mehandjiev, D., 2010. Characterization of fayalite from copper slag. Journal of the University of Chemical Technology and Metallurgy 45, 317-326.

Mithun, B.M., Narasimhan, M.C., 2015. Performance of alkali activated slag concrete mixes incorporating copper slag as fine aggregate. Journal of Cleaner Production.

doi:10.1016/j.jclepro.2015.06.026

Moura, W.A., Coutinho, D., 2004. Influence of copper slag admixture in concrete in durability properties. Ambiente Construido 4, 41-56.

Moura, W.A., Gonçalves, J.P., Lima, M.B., 2007. Copper slag waste as a supplementary cementing material to concrete. Journal of Materials Science 42, 2226-2230. doi:10.1007/s10853-006-0997-4

Najimi, M., Sobhani, J., Pourkhorshidi, A.R., 2011. Durability of copper slag contained concrete exposed to sulfate attack. Construction and Building Materials 25, 1895-1905. doi:10.1016/j.conbuildmat.2010.11.067

Nath, S.K., Kumar, S., 2013. Influence of iron making slags on strength and microstructure of fly ash geopolymer. 25th Anniversary Session for ACI 228 - Building on the Past for the Future of NDT of Concrete 38, 924-930. doi:10.1016/j.conbuildmat.2012.09.070

Nazari, A., Sanjayan, J.G., 2015. Synthesis of geopolymer from industrial wastes. Journal of Cleaner Production 99, 297-304. doi:10.1016/j.jclepro.2015.03.003

Onuaguluchi, O., 2012. Properties of Cement Based Materials Containing Copper Tailings (Doctoral Dissertation). Eastern Mediterranean University, Gazimağusa, North Cyprus.

Peyronnard, O., Benzaazoua, M., 2011. Estimation of the cementitious properties of various industrial by-products for applications requiring low mechanical strength. Resources, Conservation and Recycling 56, 22-33. doi:10.1016/j.resconrec.2011.08.008

Piatak, N.M., Seal II, R.R., Hammarstrom, J.M., 2004. Mineralogical and geochemical controls on the release of trace elements from slag produced by base- and precious-metal smelting at abandoned mine sites. A Tribute to Gunter Faure 19, 1039-1064. doi:10.1016/j.apgeochem.2004.01.005

Sánchez de Rojas, M.I., Rivera, J., Frías, M., Marín, F., 2008. Use of recycled copper slag for blended cements. Journal of Chemical Technology and Biotechnology 83, 209-217. doi:10.1002/jctb.1830

Shi, C., Meyer, C., Behnood, A., 2008. Utilization of copper slag in cement and concrete. Resources, Conservation and Recycling 52, 1115-1120. doi:10.1016/j.resconrec.2008.06.008 
Shi, C., Qian, J., 2000. High performance cementing materials from industrial slags -- a review. Resources, Conservation and Recycling 29, 195-207. doi:10.1016/S0921-3449(99)000609

Taha, R.A., Alnuaimi, A.S., Al-Jabri, K.S., Al-Harthy, A.S., 2007. Evaluation of controlled low strength materials containing industrial by-products. Building and Environment 42, 33663372. doi:10.1016/j.buildenv.2006.07.028

Tashima, M., Soriano, L., Monzó, J., Borrachero, M., Akasaki, J., Payá, J., 2014. New method to assess the pozzolanic reactivity of mineral admixtures by means of $\mathrm{pH}$ and electrical conductivity measurements in lime: pozzolan suspensions. Materiales de Construcción; Vol 64, No 316 (2014).

Thomas, B.S., Gupta, R.C., 2013. Mechanical properties and durability characteristics of concrete containing solid waste materials. Journal of Cleaner Production. doi:10.1016/j.jclepro.2013.11.019

UNE 83485:1996 EX, 1996. , Additions to concrete. Ground granulated blastfurnace slags. Determination of activity index.

UNE-EN 196-1:2005, 2005. , Methods of testing cement - Part 1: Determination of strength.

UNE-EN 197-1:2011, 2011. , Cement - Part 1: Composition, specifications and conformity criteria for common cements.

UNE-EN 450-1:2013, 2013. , Fly ash for concrete - Part 1: Definition, specifications and conformity criteria.

Zain, M.F.M., Islam, M.N., Radin, S.S., Yap, S.G., 2004. Cement-based solidification for the safe disposal of blasted copper slag. Cement and Concrete Composites 26, 845-851. doi:10.1016/j.cemconcomp.2003.08.002 